UDC 606.61:579.864: [579.2/6+612.392.98]

\title{
Bacteriocins Lactobacillus - an alternative to antimicrobial drugs
}

\author{
I. M. Voloshyna ${ }^{1,2}$, K. I. Soloshenko², V. O. Krasinko², I. V. Lych², L. V. Shkotova \\ ${ }^{1}$ Kyiv National University of Technologies and Design \\ 2, Nemirovich-Danchenko Str., Kyiv, Ukraine, 01011 \\ ${ }^{2}$ National University of Food Technologies \\ 68, Volodymyrska Str., Kyiv, Ukraine, 01601 \\ ${ }^{3}$ Institute of Molecular Biology and Genetics, NAS of Ukraine \\ 150, Akademika Zabolotnoho Str., Kyiv, Ukraine, 03143 \\ i_woloschina@yahoo.com
}

The review presents the characteristics of bacteria of the Lactobacillus family and their ability to synthesize various bacteriocins. The classification of bacteriocins of lactobacilli is given, which includes three classes: class I - lantibiotics (peptides with a molecular weight of less than $5 \mathrm{kDa}$, which contain lanthionine), class II - unmodified bacteriocins, also called nonlantibiotics (heat-resistant peptides, which do not contain lanthionine and have a molecular weight less than $10 \mathrm{kDa}$ ), and class III — a poorly studied group of thermolabile proteins with a molecular weight of more than $30 \mathrm{kDa}$. Lactobacilli are shown to synthesize a wide spectrum of bacteriocins, which demonstrate a variety of actions and are able to inhibit the growth of numerous species of opportunistic gram-positive microflora. The article also provides the examples of bacteriocins produced by Lactobacillus isolated from food products (fermented meat, fish, kombucha, goat milk, koumiss, etc.) and various human biotopes (microbiota of breast milk, intestinal tract and vaginal secretions). Additionally, the review shows the prospects of wide application of bacteriocins synthesized by Lactobacillus in the food and pharmaceutical industries.

Ke yw or d s: bacteriocins, Lactobacillus, lactococci, lactic acid bacteria, probiotics.

\section{Introduction}

There are many different medicines on the pharmaceutical market, but the trend towards an increase of morbidity is observed due to the influence of various exo- and endogenous factors that negatively affect the normal functio- ning of the main systems of human body. First of all, this is the influence of unfavorable environmental factors, unbalanced nutrition, deficiency of vitamins and microelements, increased number of stressful situations, as well

(C) 2021 I. M. Voloshyna et al.; Published by the Institute of Molecular Biology and Genetics, NAS of Ukraine on behalf of Biopolymers and Cell. This is an Open Access article distributed under the terms of the Creative Commons Attribution License (http://creativecommons.org/licenses/by/4.0/), which permits unrestricted reuse, distribution, and reproduction in any medium, provided the original work is properly cited 
as the massive uncontrolled use of chemotherapeutic drugs and antibiotics. As a result, the combination of factors listed above leads to the resistance of pathogenic microorganisms to antibiotics, which causes necessity of the development of new effective antimicrobial drugs. One of the modern trends in the search for medicines with antimicrobial activity is the use of bacteriocins [1, 42].

Bacteriocins are ribosomally synthesized peptides or proteins produced by bacteria. These compounds have antibacterial activity against other bacteria, which are usually closely associated with the producent strain [17].

Bacteriocins are synthesized by various microorganisms and have already found wide application in medicine, veterinary medicine and food technologies as a therapeutic agent, as well as a food preservative to combat various infectious and food pathogens.

Some antibiotics have harmful side effects on human health whereas bacteriocins do not have any or have little cytotoxicity $[1,9,17]$. It is mainly because the tested bacteriocins were produced by the lactic acid bacteria. The latter have been used in fermentation and milk production as bio-preservatives for a long time, and are also one of the factors of hypercolonization of the digestive tract of a healthy person with a normal microbiota. The beneficial properties of bacteriocins allow using them to replace antibiotics or stimulate their action as well as to reduce the spawn rate of antibiotic-resistant strains.

Friendly bacteria of the human microbiota can be mobilized to produce bacteriocins and prevent bacterial infection on the outer surface of the human epithelium of the gastrointestinal tract (GIT) $[9,17,36]$.

\section{Characteristics of Lactobacillus}

Lactic acid bacteria (LAB) are a diverse and extremely valuable group of microorganisms, which, without adhering to a strict taxonomic classification, are united on the basis of their general properties including a common feature: the ability to synthesize lactic acid (LA) as the main or single fermentation product [42].

Bacteria of the Lactobacillus genus are localized in almost all biotopes of the digestive tract and therefore they are referred to as the main human microbiota $[8,45]$. The genus Lactobacillus has several hundred species. Based on the analysis of the 16S rRNA sequence, lactobacilli are phylogenetically divided into seven groups: Lactobacillus buchneri (bu), Lactobacillus casei (ca), Lactobacillus delbrueckii (de), Lactobacillus plantarum (pl), Lactobacillus reuteri (re), Lactobacillus sakei (sa) and Lactobacillus salivarius (sl). Traditionally, depending on the ways of fermentation of carbohydrates, bacteria of the Lactobacillus genus are divided into three groups: (1) obligate homofermentative; (2) facultative heterofermentative; and (3) obligate heterofermentative bacteria [7].

Lactobacillus are gram-positive non-sporeforming bacteria, obligate or facultative anaerobes with high enzymatic activity, which are incredibly diverse in shape and size. They can be in the form from short to long filamentous rods, arranged singly, in pairs or in short chains. During their normal metabolism lactobacilli are capable of forming lactic acid, hydrogen peroxide, producing lysozyme and substances with antibiotic activity such as reuterin, plantaricin, lactocidin, lactolin [19]. Heterofermentative Lactobacillus species can also produce lactic, acetic, butyric, and a num- 
ber of other acids, as well as carbon dioxide $[33,36]$.

Lactobacilli possess a diverse spectrum of biological activities, for example, they help to stimulate the secretion of gastric juice and enzymes necessary for enhancement of digestion processes they are able to reduce the side effects of antibiotics, help to split bile salts and normalize lipid metabolism. Other important characteristics are the abilities to protect epithelial cells from damage, to enhance the regeneration of the intestinal mucosa, and to mitigate inflammatory processes by normalizing the general composition of microflora [22, 24].

Most of the lactic acid bacteria are able to synthesize antibiotic substances of proteinpeptide nature, which eliminate or retard the growth of related bacteria species and/or strains; additionally, they have a wide spectrum of antibacterial activity and therefore are called bacteriocins. Basically, bacteriocins are thermostable substances with a high molecular weight (up to 10-30 kDa). Their biosynthesis is encoded by special plasmids and occurs on ribosomes [13, 25].

It is of importance to discuss the classification and properties of lactobacilli bacteriocins in more detail.

\section{Classification of bacteriocins}

Bacteriocins are conventionally divided into three classes: class I - lantibiotics, class II unmodified bacteriocins, which are also called non-lantibiotics [12, 25, 27], and class III, which includes a group of thermolabile proteins with a molecular weight of more than $30 \mathrm{kDa}$ [38].

Bacteriocins of class I are peptides with a molecular weight of less than $5 \mathrm{kDa}$, which contain lanthionine. They include such amino acids as lanthionine (Lan), $\alpha$-methylanthionine (MeLan), dehydroalanine and dehydrobutyrine. According to the chemical structure and antimicrobial properties, this class is divided into the types A and B lantibiotics [10, 25]. The type A lantibiotics are small cationic peptides, which exhibit antibacterial activity by forming pores in bacterial membranes. The representatives of type $B$ are small anionic or neutral globular peptides, the antimicrobial properties of which are manifested by inhibiting specific enzymes.

Bacteriocins of class II are heat-resistant peptides, which do not contain lanthionine and have a molecular weight less than $10 \mathrm{kDa}[5$, $10,25]$. The representatives of this group exhibit antimicrobial activity against Listeria genus; they are capable of destroying the integrity of the microbial membrane, which leads to ionic imbalance and loss of organic phosphorus in target cells. The representatives of this class are divided into four subgroups. Class IIa includes pediocin-shaped bacteriocins, they contain the N-terminal sequence Tyr-Gly-Asn-Gly-Val-Xaa-Cys (TGAGV). Class IIb consists of two-peptide bacteriocins, the activity of which depends on two different peptides. These two peptides can show their activity independently of each other, but exhibit synergism when they function together. Class IIc includes cyclic bacteriocins and class IId - unmodified linear non-pediocineshaped bacteriocins [5, 10, 25].

Bacteriocins of class III include a group of thermolabile proteins with a molecular weight more than $30 \mathrm{kDa}$. Unfortunately, their properties have not yet been studied enough [25, 38, 39]. 


\section{Variety of bacteriocins produced by Lactobacillus}

Lactobacilli synthesize a wide spectrum of bacteriocins. These substances have a variety of actions and inhibit the growth of numerous species of opportunistic gram-positive microflora, for example, Listeria monocytogenes, Clostridium butyricum, Clostridium sporogenes, Staphylococcus aureus, Enterococcus faecalis, Bacillus spp. and others. The synthesis of active bacteriocins is one of the factors that provide high colonization properties and play a regulatory role of lactobacilli in maintaining the physiological microbial balance in biocenoses [13].

Most of the bacteriocins are small molecules with amphiphilic properties and high isoelectric points. The producent cells are resistant to the bacteriocins they produce due to the synthesis of specific immunity proteins $[11,21]$.

Currently, an active research is underway on the mechanisms of the antimicrobial action of bacteriocins. It was found that lactobacilli bacteriocins contain the protein components, which are fixed on specific cellular receptors of target cells and disrupt the transport of various cations through the cell membrane of microorganisms. The most studied bacteriocins of Lactobacillus are amilovorin 471 (L. amylovorus 471119), acidocin B (L. acidophilus), bavaricin $\mathrm{MN}$ (L. bavaricus $\mathrm{MN})$, caseicin (L. casei), curvacin FS47 and A (L. curvatus FS47 and L. curvatus LTH1174), lactocin S (L. sake L 45), plantaricin A and C (L. plantarum), plantacin 154 (L. plantarum LTF154), sakacin 674 (L. sake Lb674), etc. [11]. The literature contains also information about new bacteriocins of Lactobacillus, such as salivaricin mmaye1 (L. salivarius), BacF1 and
BacF2 (L. plantarum subsp. argentoratensis SJ33) $[1,44]$.

\section{Bacteriocins of Lactobacillus, isolated from food}

Due to the unique properties, bacteriocins are widely utilized in the food industry. They are used as preservatives in partially purified or purified concentrated form. Until recently, such bacteriocins as nisin and pediocin PA-1 were licensed as food preservatives [41]. Noteworthy, the use of bacteriocins reduces the cost of production and preservation of foodstuffs retaining their nutritional and biological value.

Lactic acid bacteria (LAB) are important in the technologies of fermented food production, where their role is to prevent the growth of pathogenic microorganisms and spoilage in general. It is due to acidifying the environment and active synthesis of antimicrobial compounds, which contributes not only to quality improvement, but also to safety advancement [3].

Lactic acid bacteria, especially Lactobacillus sakei and Lactobacillus curvatus, are a part of the microbiota of many fermented meat products. These species are well adapted to the meat environment, providing an improved flavor and accelerated maturation of the fermented meat products $[15,26]$.

Bacteriocins produced by the lactic acid bacteria are well known for their activity against Listeria monocytogenes, a common gram-positive pathogen which caused several outbreaks of foodborne disease in recent decades. In one of the classifications of bacteriocins there is a special class, which includes bacteriocins with the activity against Listeria [21]. The control of L. monocytogenes in food is a major challenge due to its ability to survive 
at low $\mathrm{pH}$ values, increased salt concentration and the presence of nitrites, which are harmful to most other pathogenic microorganisms in the production of dry fermented food. Because of this, the bacteriocinogenic lactic acid bacteria and their bacteriocins are helpful as preservatives in fermented food products and can be used as technological alternatives to chemical preservatives, satisfying the demand for foods with fewer or no additives [15].

In recent years, the demand for "natural" products has increased, because consumers prefer them over foods with chemical preservatives. The critical issues connected with natural products are how to maintain their safety and quality, and how to extend their shelf life. In this regard, great attention is paid to the use of the antagonistic characteristics of lactobacilli. It was shown that Lactobacillus plantarum SLG10, isolated from kombucha (a traditional fermented drink in South China), produced bacteriocin SLG10, which had antibacterial activity against both gram-positive and gram-negative bacteria, including multidrugresistant strains. Bacteriocin SLG10 was characterized by thermal stability, $\mathrm{pH}$ tolerance, and was sensitive to most proteases, but not to trypsin or pepsin. The study of the antibacterial mechanism showed that bacteriocin SLG10 increases the permeability of the cell membrane, inducing the release of potassium ions, and can inhibit the formation of biofilms [30].

Recently, a large number of antibiotic-resistant bacteria have been found in dairy products, for example, Salmonella enterica in dry milk nutrition, Staphylococcus aureus in raw and pasteurized milk and in ice cream and vancomycin-resistant Enterococcus faecium in cheeses $[15,31]$. There is information in the literature that some bacteriocins produced by lactic acid bacteria can inhibit foodborne multidrug-resistant pathogens, which favorably distinguishes them from other registered bacteriocins with a rather narrow inhibitory spectrum $[24,26]$.

Researchers pay great attention to studying the characteristics of the production of natural preservatives by lactic acid bacteria. Thus, it was shown that the biosynthesis of bacteriocins by L. curvatus $\mathrm{MBSa} 2$ and $\mathrm{MBSa} 3$ on the MRS medium begins in the early exponential growth phase ( $4 \mathrm{~h}$ of cultivation). Under the cultivation conditions at $37^{\circ} \mathrm{C}$, after $12 \mathrm{~h}$ the amount of produced bacteriocins began to decrease in both strains. Maximum accumulation of MBSa2 bacteriocin $(12800 \mathrm{U} / \mathrm{ml})$ was observed after 8-hour cultivation at $25^{\circ} \mathrm{C}$ and $37{ }^{\circ} \mathrm{C}$ and 6-hour cultivation at $30^{\circ} \mathrm{C}$. This indicates the primary kinetics of the metabolite, which is also observed for other bacteriocins, such as sakacin K (producent L. sakei CTC 494), sakacin P (L. sakei CCUG 42687), curvacin A (L. curvatus LTH 1174), curvaticin L442 (L. curvatus L422) [2, 4].

The Literature data point out that many bacteriocins are thermostable, because they retain their properties after heat treatment $\left(100-120^{\circ} \mathrm{C}, 15 \mathrm{~min}\right)[4,44,46]$. This indicates that they can be used in the heat-treated foods without a decrease in their preservative action. Usually the low molecular weight bacteriocins are thermostable because they are small polypeptides. These properties have been described for bacteriocins MBSa2 and MBSa3 (L. curvatus), sakacin $\mathrm{M}$ and $\mathrm{P}$ (L. sakei), pediocin L50 (Pediococcus pentosaceus), acidocin D20079 (L. acidophilus), plantaricin LP31 (L. plantarum) [4]. 
In view of the unique properties and expanding prospects for the use of bacteriocins of lactic acid bacteria in food technologies, researchers are active in search for and isolation of producents of these biologically active compounds from traditional food products and raw materials. Thus, the Lactobacillus crustorum strain isolated from koumiss (Xinjiang, China) can produce bacteriocin MN047 A [46]. Koumiss is a traditional fermented mare's milk, popular in the Central Asian steppes, including China, Mongolia, Kazakhstan, Kyrgyzstan and some regions of Russia. For centuries, koumiss was considered not only a drink, but also a functional food product for medical purposes, such as improving function of kidneys, gastrointestinal tract, nervous system and immune system, and treatment of hepatitis, chronic ulcers, tuberculosis, etc. [46]. Koumiss is usually obtained from mare's milk by fermenting its own natural microbiota, including lactic acid bacteria and yeast. Various strains of Lactobacillus, including L. casei, L. plantarum, L. fermentum, L. helveticus and L. acidophilus, have been found in koumiss but only bacteriocin produced by L. plantarum has been purified and characterized [26, 35, 42, 45].

More and more researchers are engaged in a comprehensive study of the properties of isolated bacteriocins. Thus, bacteriocin LF-BZ532 synthesized by Lactobacillus fermentum BZ532 appears to be promising for further practical use. This strain was isolated from a Chinese fermented grain drink (bozai) and identified by $16 \mathrm{~s}$ rRNA sequencing. Bacteriocin LF-BZ532 has a molecular weight of $1105.563 \mathrm{Da}$ [32]. It was found that this bacteriocin possesses a wide spectrum of an- timicrobial activity against gram-positive and gram-negative bacteria, including Listeria and Pseudomonas. The unique properties of the described bacteriocin are its significant thermal stability with a residual activity of $88.19 \%$ and $56.98 \%$ at 100 and $121{ }^{\circ} \mathrm{C}(30,20 \mathrm{~min})$ respectively. Additionally, it is stable over a wide $\mathrm{pH}$ range (2-8), but it is highly sensitive to the action of proteolytic (proteinase K, pepsin, and trypsin) enzymes, which indicates its peptide nature. Based on the foregoing, it is assumed that purified LF-BZ532 and its producing strain L. fermentum BZ532 are promising candidates for use as a bioconservative in the food industry [32].

The Lactobacillus sakei GM3 strain isolated from goat milk exhibited resistance to acid and bile and showed antagonistic activity against foodborne pathogens. The Bacteriocin production observed in L. sakei GM3 reached its maximum in the stationary phase, after 18 hours of cultivation $[2,3]$. The study of the properties of bacteriocin GM3 showed that it remains active in a wide $\mathrm{pH}$ and temperature ranges, it is resistant to organic solvent. At the same time, bacteriocin GM3 is sensitive to some proteolytic enzymes. It was found that the molecular weight of bacteriocin is $4.8 \mathrm{kDa}$. The study of cytotoxicity in the model of HT29 cells showed the maximum inhibition of survival $(45.60 \pm 0.5 \%)$ at a bacteriocin concentration of $2240 \mathrm{U} / \mathrm{ml}$. These results indicate that the L. sakei GM3 has potential for use in the food industry as a biopreservative [2].

Bacteriocin DY4-2, synthesized by the strain Lactobacillus plantarum DY4-2, which was isolated from saber fish (Trichiurus lepturus) is quite interesting. This bacteriocin is maximally synthesized in the stationary phase 
after $24 \mathrm{~h}$ of incubation. The molecular weight of bacteriocin DY4-2 was determined to be 1465 Da. Bacteriocin DY4-2 was characterized by significant thermal stability $(30 \mathrm{~min}$ at $121{ }^{\circ} \mathrm{C}$ ) preserving activity in the $\mathrm{pH}$ range $2.5-5.5$, but was sensitive to the proteolytic enzymes. This bacteriocin exhibited a wide spectrum of antimicrobial activity against fish pathogenic bacteria, such as Pseudomonas fluorescens, P. aeruginosa, Vibrio parahaemolyticus, Aeromonas sobria, and Listeria monocytogenes $[28,30]$. The addition of partially purified bacteriocin DY4-2 to halibut fillets reduced the number of $P$. fluorescens cells by $2.7 \log$ units at $4{ }^{\circ} \mathrm{C}$ for 12 days. If compared with the control, the samples treated with bacteriocin DY4-2 showed a significant decrease in the total number of viable microorganisms. The results of these studies demonstrated that bacteriocin DY4-2 possesses the potential to act as a bio-preservative for seafood [28].

Highly appreciating the prospects of biotechnological production of bacteriocins, researchers select the substrates for the most cost-effective biosynthesis. Thus, whey, the main by-product obtained after curdling and removing casein in cheese production, is a large-scale waste in the dairy industry $[6,42]$. When whey is discharged into water, it weakly biodegradates but the level of dissolved oxygen reduces, which negatively affects the normal natural processes of self-cleaning of water objects and creates a real risk to the life of aquatic inhabitants. The practice of uncontrolled discharge of wastewater containing whey leads to many environmental problems: severe environmental pollution affecting the physicochemical characteristics of the soil, which in turn results in a decreased yield. Thus, the search for the cheap methods of whey utilization remains relevant $[6,25]$.

Because whey makes up about $55 \%$ of all milk nutrients, an economical and profitable alternative is to use it as a substrate for the production of biologically active substances. The most common whey nutrients are lactose (75\%), soluble proteins (12 .. $14 \%$ ), lipids and mineral salts $(1 \ldots 10 \%)$. They are necessary for the growth of microorganisms, especially for lactic acid bacteria, which are widely used in the food industry [6]. Although bacteriocins can be produced by numerous microorganisms, those produced by lactic acid bacteria are attracting increased attention because they are considered the most "safe" [3]. L. plantarum species can adapt to various niches due to its ability to ferment a wide range of carbohydrates [35]. In particular, the L. plantarum ST16Pa strain can actively grow on the whey based medium and produce a peptide with a molecular weight of $6.5 \mathrm{kDa}$, exhibiting antimicrobial activity against many different food pathogenic bacteria, including gram-negative bacteria [35].

Although whey can support the growth of most lactic acid bacteria, it lacks nitrogen and other nutrients; therefore the exogenous addition of the latter is required for the successful biosynthesis of bacteriocins. Thus, the researchers demonstrated the ability of the L. plantarum ST16 strain cultivated on MRS medium to synthesize bacteriocins with high antimicrobial activity against several microorganisms. However this strain cultivated on cheese whey does not produce bacteriocin despite the accumulation of biomass [35]. 


\section{Lactobacillus bacteriocins isolated from human}

The normal microbiota of human body plays a significant role in human health. The exceptional function of human symbiotic microorganisms in protection against pathogens, maintenance of stable immunity, and biosynthesis of vital compounds such as vitamins, organic acids, amino acids, etc. has been proven $[18,40]$.

Lactobacillus bacteria are typical inhabitants of the digestive tract of humans and animals [40, 42]. Microorganisms of normal human microbiota are one of the safest sources of bacteriocins. These bacteriocins are involved in the mechanisms of antagonistic activity inside the human body, and are also used to maintain its microbiota in a state of dynamic equilibrium. The ability to produce bacteriocins is an important characteristic of probiotic strains.

According to the requirements of FAO / WHO (2002), probiotic bacteria should have a high ability to survive in the gastrointestinal tract and adhere to intestinal epithelial cells, and, most importantly, should be safe strains for humans and animals [18, 20, 42]. Because lactobacilli are considered safe probiotic microorganisms, they are widely used in the food industry to obtain various products (vegetables, meat, dairy, etc.). Therefore, the researches devoted to the search, isolation and study of lactobacilli bacteriocins from the human body appear in the scientific literature more and more often.

Thus, the results of research have been published in which Lactobacillus bacteriocins were isolated from breast milk. Sixty breast milk samples were collected from volunteer mothers aged 19 to 35 from rural areas of
Lorestan and Markazi provinces, Iran. [29]. The isolates were identified using a PCR primer specific for Lactobacillus and it was shown that eighteen out of thirty-three isolates were the Lactobacillus strains. Lactobacillus reuteri and $L$. gasseri were identified among these isolates, which survived at low $\mathrm{pH}$ values and in the presence of bile salts. It was also shown that all Lactobacillus isolates inhibit the growth of pathogen strains, and the genes associated with the bacteriocin production were found in some of these isolates [29].

The composition of microbiota of the human intestinal tract begins to form even before the birth. The child receives microorganisms through the birth canal [37, 42], as well as with breast milk. A typical childhood type of intestinal microbiota formed soon after birth is characterized by high concentrations of representatives of the genera Bifidobacterium and Lactobacillus [19]. It was logical to assume that representatives of the intestinal microbiota can be a source of obtaining the bacteriocins.

Reutericin 6, determined by mass spectrometry, is a bacteriocin with a molecular weight of $5652 \mathrm{D}$, produced by Lactobacillus reuteri LA6, which was isolated from the feces of a human infant at the age of 2 months. The primary structure of reutericin 6 by the molecular weight was identical to gassericin A produced by Lactobacillus gasseri LA39, which was isolated from the feces of the same human infant at the age of 4 months. It has been shown that reutericin 6 belongs to cyclic bactericins of class IIc. PCR amplification on chromosomal DNA of $L$. reuteri LA6 as matrix with cloned primers based on DNA sequences (gassericin A and acidocin B from Lactobacillus 
acidophilus M46) and sequencing showed that L. reuteri LA6 possesses a structural gene which is specific of gassericin A. These results demonstrate that bacteriocin with the same structure was produced by different species of lactobacilli isolated from the same infant [23].

The intestinal microbiota of adults can unite representatives of more than 600 different genera, including many representatives of the Lactobacillus genus [14, 42]. Scientists have found that $L$. salivarius strain SPW1 isolated from human feces synthesizes a new bacteriocin salivaricin mmaye 1. L. salivarius belongs to the main components of the human intestinal microbiota and does not exhibit any toxicity $[16,42]$. It also has probiotic properties and improves people and animal health [43].

It has been shown that salivaricin mmaye 1 has a molecular weight of about $1221 \mathrm{Da}$, it is associated with the cell wall, is effective at micromolar concentrations, and has a wide spectrum of antibacterial activity. Besides, salivaricin mmaye 1 showed high thermal and chemical stability and moderate stability at different $\mathrm{pH}$ values [43].

The studies, carried out within the framework of the Human Microbiome project, revealed that Lactobacillus species dominate in the microbiota of reproductive tract of women $[18,42]$.

Lactobacilli, which were isolated from human vaginal secretions, were tested for the production of antimicrobial substances with the potential to provide physiological protection against pathogenic microorganisms in the vaginal area [34]. About $10 \%$ of the isolates showed antibacterial activity against one or more closely related microorganisms used as indicators. Lactobacillus fermentum CS57 was the best producent and secreted a bacteriocinlike substance with antagonistic activity against Streptococcus agalactiae and Candida albicans. These substances were sensitive to proteolytic enzymes and resistant to high temperatures. The mechanism of their action was identified as bactericidal, and the molecular weight was determined as more than $30 \mathrm{kDa}$. Taking into account all the results, the authors consider it possible to use L. fermentum CS57 as a probiotic for the prevention of human vaginal infections [34].

There is rather interesting information about the results of a study of heat-resistant bacteriocin salivaricin CRL 1328, which was synthesized by Lactobacillus salivarius CRL 1328. The scientists isolated this strain from the vagina of a healthy woman and established that this substance can be successfully used for the prevention of urogenital infections [31].

Thus, lactobacilli, the representatives of normal human microbiota, are the most promising source of bacteriocins, considering the safety of strains, which also have probiotic significance.

\section{Conclusions}

In view of the spreading resistance of pathogenic microorganisms to antibiotics, one of the modern trends in the search for medicines with antimicrobial activity is the use of bacteriocins - the substances of a protein-peptide nature with a wide spectrum of antimicrobial activity.

Bacteriocins are conventionally divided into three classes due to their molecular weight, structure and relation to temperature.

Bacteriocins of lactic acid bacteria can be isolated from various biotopes of humans, as 
well as from various fermented food and milk products.

Promising directions for obtaining Lactobacillus bacteriocins include the stages of isolation of microbial cultures from natural sources, screening of the most active producents, and experimental enhancement of the producent's activity, including classical methods of mutagenesis and genetic engineering manipulations.

Bacteriocins of Lactobacillus can be used in medicine, veterinary medicine and food industry as an effective and safe alternative to antibiotics and food preservatives.

\section{REFERENCES}

1. Ray Mohapatra A, Jeevaratnam K. Inhibiting bacterial colonization on catheters: Antibacterial and antibiofilm activities of bacteriocins from Lactobacillus plantarum SJ33. J Glob Antimicrob Resist. 2019;19:85-92.

2. Avaiyarasi ND, Ravindran AD, Venkatesh P, Arul V. In vitro selection, characterization and cytotoxic effect of bacteriocin of Lactobacillus sakei GM3 isolated from goat milk. Food Control. 2016; 69:124-33.

3. Balciunas EM, Martinez FAC, Todorov SD, de Melo Franco BDG, Converti A, de Souza Oliveira RP. Novel biotechnological applications of bacteriocins: A review. Food Control. 2013; 32(1):134-42.

4. de Souza Barbosa M, Todorov SD, Ivanova I, Chobert JM, Haertlé T, de Melo Franco BDG. Improving safety of salami by application of bacteriocins produced by an autochthonous Lactobacillus curvatus isolate. Food Microbiol. 2015;46:254-262.

5. Belguesmia Y, Naghmouchi K, Chihib NE, Drider D. Class IIa Bacteriocins: Current Knowledge and Perspectives. In: Drider D., Rebuffat S. (eds) Prokaryotic Antimicrobial Peptides. 2011. Springer, New York, NY. 171-95.

6. Brandelli A, Sala L, Kalil SJ. Microbial enzymes for bioconversion of poultry waste into added-value products. Food Res Int. 2015; 73:3-12.
7. De Angelis M, Gobbetti M. Lactobacillus spp.: General Characteristics. Reference Module in Food Sci. 2016.

8. Dhama K, Latheef SK, Munjal AK, Khandia R, Samad HA, Iqbal HMN, Joshi SK. Probiotics in Curing Allergic and Inflammatory Conditions Research Progress and Futuristic Vision. Recent Pat Inflamm Allergy Drug Discov. 2017;10(2):105-118.

9. Dicks LMT, Dreyer L, Smith C, van Staden AD. A Review: The Fate of Bacteriocins in the Human Gastro-Intestinal Tract: Do They Cross the GutBlood Barrier? Front Microbiol. 2018;9:2297.

10. Diep DB, Skaugen M, Salehian Z, Holo H, Nes IF. Common mechanisms of target cell recognition and immunity for class II bacteriocins. Proc Natl Acad Sci U S A. 2007;104(7):2384-9.

11. Dobson A, Cotter PD, Ross RP, Hill C. Bacteriocin production: a probiotic trait? Appl Environ Microbiol. 2012;78(1):1-6.

12. Drider D, Fimland G, Héchard Y, McMullen LM, Prévost $H$. The continuing story of class IIa bacteriocins. Microbiol Mol Biol Rev. 2006;70(2):564-82.

13. Egorov NS, Baranova IP. Bakteriotsiny. Obrazovanie, svoüstva, primenenie [Bacteriocins. Production, properties, application]. Antibiot Khimioter. 1999;44(6):33-40.

14. Falony $G$, Joossens $M$, Vieira-Silva S, Wang J, Darzi Y, Faust K, Kurilshikov A, Bonder MJ, VallesColomer M, Vandeputte D, Tito RY, Chaffron $S$, Rymenans L, Verspecht C, De Sutter L, Lima-Mendez G, D'hoe K, Jonckheere K, Homola D, Garcia R, Tigchelaar EF, Eeckhaudt L, Fu J, Henckaerts L, Zhernakova A, Wijmenga C, Raes J. Population-level analysis of gut microbiome variation. Science. 2016;352(6285):560-4.

15. Gálvez A, Abriouel H, López RL, Ben Omar N. Bacteriocin-based strategies for food biopreservation. Int J Food Microbiol. 2007;120(1-2):51-70.

16. Guinane CM, Piper C, Draper LA, O'Connor PM, Hill C, Ross RP, Cotter PD. Impact of Environmental Factors on Bacteriocin Promoter Activity in Gut-Derived Lactobacillus salivarius. Appl Environ Microbiol. 2015;81(22):7851-9.

17. Hols P, Ledesma-García L, Gabant P, Mignolet J. Mobilization of Microbiota Commensals and Their 
Bacteriocins for Therapeutics. Trends Microbiol. 2019;27(8):690-702.

18. Human Microbiome Project Consortium. Structure, function and diversity of the healthy human microbiome. Nature. 2012;486(7402):207-14.

19. Jakobsson HE, Abrahamsson TR, Jenmalm MC, Harris K, Quince C, Jernberg C, Björkstén B, Engstrand L, Andersson AF. Decreased gut microbiota diversity, delayed Bacteroidetes colonisation and reduced Th1 responses in infants delivered by caesarean section. Gut. 2014;63(4):559-66.

20. Jia FF, Zhang LJ, Pang XH, Gu XX, Abdelazez A, Liang $Y$, Sun SR, Meng XC. Complete genome sequence of bacteriocin-producing Lactobacillus plantarum KLDS1.0391, a probiotic strain with gastrointestinal tract resistance and adhesion to the intestinal epithelial cells. Genomics. 2017;109(5-6):432-437.

21. Kalyuzhin OV. Probioticheskie shtammy` laktobacill kak immunomodulyatory`: v fokuse - Lactobacillus rham-nosus GG. Medicinskij sovet. 2017; 9:108-15.

22. Kato S, Hamouda N, Kano Y, Oikawa Y, Tanaka Y, Matsumoto K, Amagase K, Shimakawa M. Probiotic Bifidobacterium bifidum G9-1 attenuates 5-fluorouracil-induced intestinal mucositis in mice via suppression of dysbiosis-related secondary inflammatory responses. Clin Exp Pharmacol Physiol. 2017;44(10):1017-1025.

23. Kawai Y, Ishii Y, Uemura K, Kitazawa H, Saito T, Itoh $T$. Lactobacillus reuteri LA6 and Lactobacillus gasseri LA39 isolated from faeces of the same human infant produce identical cyclic bacteriocin. Food Microbiol. 2001; 18(4):407-15.

24. Kim MS, Byun JS, Yoon YS, Yum DY, Chung MJ, Lee JC. A probiotic combination attenuates experimental colitis through inhibition of innate cytokine production. Benef Microbes. 2017;8(2):231-241.

25. Kumariya R, Garsa AK, Rajput YS, Sood SK, Akhtar N, Patel S. Bacteriocins: Classification, synthesis, mechanism of action and resistance development in food spoilage causing bacteria. Microb Pathog. 2019;128:171-177.

26. Lahtinen SJ, Forssten S, Aakko J, Granlund L, Rautonen N, Salminen S, Vitanen M, Ouwehand AC. Probiotic cheese containing Lactobacillus rhamnosus HN001 and Lactobacillus acidophilus NCFM® modifies subpopulations of fecal lactobacilli and Clostridium difficile in the elderly. Age (Dordr). 2012;34(1):133-43.

27. Liu W, Pang H, Zhang H, Cai Y. Biodiversity of lactic acid bacteria. Springer. 2014; 103-203.

28. Lv X, Ma H, Sun M, Lin Y, Bai F, Li J, Zhang B. A novel bacteriocin DY4-2 produced by Lactobacillus plantarum from cutlass fish and its application as bio-preservative for the control of Pseudomonas fluorescens in fresh turbot (Scophthalmus maximus) fillets. Food Control. 2018; 89:22-31.

29. Mohammadi F, Eshaghi M, Razavi S, Sarokhalil DD, Talebi M, Pourshafie MR. Characterization of bacteriocin production in Lactobacillus spp. isolated from mother's milk. Microb Pathog. 2018;118:242246.

30. Pei J, Jin W, Abd El-Aty AM, Baranenko DA, Gou X, Zhang $H$, Yue $T$. Isolation, purification, and structural iden-tification of a new bacteriocin made by Lactobacillus plantarum found in conventional kombucha. Food Control. 2020; 110:106923.

31. Vera Pingitore E, Hébert EM, Nader-Macías ME, Sesma F. Characterization of salivaricin CRL 1328, a two-peptide bacteriocin produced by Lactobacillus salivarius CRL 1328 isolated from the human vagina. Res Microbiol. 2009;160(6):401-8.

32. Rasheed HA, Tuoheti T, Zhang Y, Fidelis A, Tekliye $M$, Dong $M$. Purification and partial characte-ri-zation of a novel bacteriocin produced by bacteriocinogenic Lactobacillus fermentum BZ532 isolated from Chinese fer-mented cereal beverage (Bozai). LWT-Food Sci Technol. 2020; 124:109-13.

33. Rubel M, Voloshyna I. The use of probiotic microorganisms in cosmetic medical products. Scientific Works Of National University Of Food Technologies. 2014; 2(20):23-9.

34. Sabia C, Anacarso I, Bergonzini A, Gargiulo $R$, Sarti $M$, Cond $C$, Bondi $M$. Detection and partial characterization of a bacteriocin-like substance produced by Lactobacillus fermentum CS57 isolated from human vaginal secretions. Anaerobe. 2014; 26:41-5.

35. Sabo SS, Converti A, Ichiwaki S, Oliveira RPS. Bacteriocin production by Lactobacillus plantarum 
ST16Pa in supplemented whey powder formulations. J Dairy Sci. 2019;102(1):87-99.

36. Sender R, Fuchs S, Milo R. Revised Estimates for the Number of Human and Bacteria Cells in the Body. PLoS Biol. 2016;14(8):e1002533.

37. Stinson LF, Payne MS, Keelan JA. Planting the seed: Origins, composition, and postnatal health significance of the fetal gastrointestinal microbiota. Crit Rev Microbiol. 2017;43(3):352-369.

38. Sun Z, Wang X, Zhang X, Wu H, Zou Y, Li P, Sun $C$, $X u W$, Liu F, Wang $D$. Class III bacteriocin Helveticin-M causes sublethal damage on target cells through impairment of cell wall and membrane. J Ind Microbiol Biotechnol. 2018;45(3): 213-227.

39. Thompson JK, Collins MA, Mercer WD. Characterization of a proteinaceous antimicrobial produced by Lactobacillus helveticus CNRZ450. J Appl Bacteriol. 1996;80(3):338-48.

40. van Baarlen P, Wells JM, Kleerebezem M. Regulation of intestinal homeostasis and immunity with probiotic lactobacilli. Trends Immunol. 2013;34(5): 208-15.

41. Vijay Simha B, Sood SK, Kumariya R, Garsa AK. Simple and rapid purification of pediocin PA-1 from Pediococcus pentosaceous NCDC 273 suitable for industrial application. Microbiol Res. 2012;167(9): 544-9.

42. Voloshyna IM, Shkotova LV, Skorokhod SO, Appolonova IY, Zholobak NM. Lactobacillus bacteria: biological and therapeutic properties. Mikrobiol Z. 2019; 81(6):131-46.

43. Wayah SB, Philip K. Purification, characterization, mode of action, and enhanced production of Salivaricin mmaye1, a novel bacteriocin from Lactobacillus salivarius SPW1 of human gut origin. Electron J Biotechnol. 2018; 35:39-47.

44. Wu CT, Chen PJ, Lee YT, Ko JL, Lue KH. Effects of immunomodulatory supplementation with Lactobacillus rhamnosus on airway inflammation in a mouse asthma model. J Microbiol Immunol Infect. 2016;49(5):625-635.

45. Yi L, Dang Y, Wu J, Zhang L, Liu X, Liu B, Zhou Y, $L u X$. Purification and characterization of a novel bacteriocin produced by Lactobacillus crustorum
MN047 isolated from koumiss from Xinjiang, China. J Dairy Sci. 2016;99(9):7002-7015.

\section{Бактериоцини Lactobacillus - альтернатива антимікробних препаратів}

I. М. Волошина, К. І. Солошенко, В. О. Красінько, І. В. Лич, Л. В. Шкотова

В огляді наведено літературні дані щодо характеристики бактерій родини Lactobacillus i їх здатність синтезувати різні бактеріоцини. Показана класифікація бактеріоцинів лактобактерій, яка включає три класи: I клас - лантібіотікі (містять лантіонін і є пептидами 3 молекулярної масою менш 5 кДа), II клас - немодифіковані бактеріоцини, які також називаються нелантібіотікі (термостійкі пептиди, що не містять лантіонін і мають молекулярну масу менше 10 кДа) і III клас мало вивчену групу термолабільних білків з молекулярною масою понад 30 кДа. Показано, що Lactobacillus синтезують дуже широкий спектр бактеріоцинів, які володіють різноманіттям дії і здатні інгібувати ріст великої кількості різних видів умовно-патогенної грампозитивної мікрофлори. Також в статті наведені приклади бактеріоцинів лактобактерій, які виділені з харчових продуктів (ферментованого м'яса, риби, чайного гриба, козячого молока, кумису і т.д.) і різних біотопів людини (мікробіоти материнського молока, кишкового тракту і вагінального секрету). Показана перспективність широкого застосування синтезованих лактобактеріями бактеріоцинів в харчовій і фармацевтичній галузях промисловості.

К л юч о в і с л о в а: бактеріоцини, Lactobacillus, лактококи, молочнокислі бактерії, пробіотики.

\section{Бактериоцини Lactobacillus - альтернатива антимикробных препаратов}

И. Н. Волошина, К. И. Солошенко,

В. О. Красинько, И. В. Лыч, Л. В. Шкотова

В обзоре приведены литературные данные относительно характеристики бактерий семейства Lactobacillus и их способность синтезировать различные бактериоцины. Показана классификация бактериоцинов лактобактерий, которая включает три класса: I класс — лантибиотики (содержат лантионин и является пептидами с молекулярной массой менее 5 кДа), II класс - не- 
модифицированные бактериоцины, которые также называются нелантибиотики (термостойкие пептиды, не содержащие лантионин и имеющие молекулярную массу меньше 10 кДа) и III класс — мало изученную группу термолабильных белков с молекулярной массой более 30 кДа. Показано, что Lactobacillus синтезируют очень широкий спектр бактериоцинов, которые обладают многообразием действия и способны ингибировать рост многочисленных видов условно-патогенной грамположительной микрофлоры. Также в статье приведены примеры бактериоцинов лактобактерий, которые выделены из пищевых продуктов (ферментиро- ванного мяса, рыбы, чайного гриба, козьего молока, кумыса и т.д.) и различных биотопов человека (микробиоты материнского молока, кишечного тракта и влагалищного секрета). Показана перспективность широкого применения синтезированных лактобактериями бактериоцинов в пищевой и фармацевтической отраслях промышленностях.

Кл юче в ы е сл ов а: бактериоцины, Lactobacillus, лактококки, молочнокислые бактерии, пробиотики.

Received 22.10.2020 